\title{
Cancer cell adaptation to chemotherapy
} Federica Di Nicolantonio ${ }^{1}$, Stuart J Mercer ${ }^{1}$, Louise A Knight ${ }^{1}$, Francis G Gabriel ${ }^{1}$, Pauline A Whitehouse ${ }^{1}$, Sanjay Sharma ${ }^{1}$, Augusta Fernando ${ }^{1}$, Sharon Glaysher ${ }^{1}$, Silvana Di Palma ${ }^{1}$, Penny Johnson ${ }^{1}$, Shaw S Somers², Simon Toh ${ }^{2}$, Bernie Higgins ${ }^{3}$, Alan Lamont ${ }^{4}$, Tim Gulliford ${ }^{5}$, Jeremy Hurren ${ }^{2}$, Constantinos Yiangou ${ }^{2}$ and Ian A Cree*1

\author{
Address: ${ }^{1}$ Translational Oncology Research Centre, Department of Histopathology, Queen Alexandra Hospital, Portsmouth PO6 3LY, UK, \\ 2Department of Surgery, Queen Alexandra Hospital, Portsmouth PO6 3LY, UK, ${ }^{3}$ Department of Mathematics and Statistics, University of \\ Portsmouth, Buckingham Building, Lion Terrace, Portsmouth PO1 3HE, UK, ${ }^{4}$ Department of Radiotherapy and Oncology, Southend Hospital, \\ Prittlewell Chase, Westcliff-on-Sea, Essex SSO ORY, UK and ${ }^{5}$ Department of Radiotherapy and Oncology, St Mary's Hospital, Milton Road, \\ Portsmouth PO3 6AD, UK \\ Email: Federica Di Nicolantonio - federicadn@hotmail.com; Stuart J Mercer - mercersurgeon@hotmail.com; \\ Louise A Knight - louise.knight@porthosp.nhs.uk; Francis G Gabriel - francis.gabriel@porthosp.nhs.uk; \\ Pauline A Whitehouse - pwhitehouse@doctors.org.uk; Sanjay Sharma - sanjay.sharma@porthosp.nhs.uk; \\ Augusta Fernando - augusta.fernando@porthosp.nhs.uk; Sharon Glaysher - sharon.glaysher@porthosp.nhs.uk; Silvana Di \\ Palma - silvana.dipalma@royalsurrey.nhs.uk; Penny Johnson - penny.johnson@porthosp.nhs.uk; \\ Shaw S Somers - shaw.somers@porthosp.nhs.uk; Simon Toh - simon.toh@porthosp.nhs.uk; Bernie Higgins - bernard.higgins@port.ac.uk; \\ Alan Lamont - alan.lamont@southend.nhs.uk; Tim Gulliford - tim.gulliford@porthosp.nhs.uk; \\ Jeremy Hurren - jeremy.hurren@porthosp.nhs.uk; Constantinos Yiangou - constantinos.yiangou@porthosp.nhs.uk; \\ Ian A Cree* - ian.cree@porthosp.nhs.uk \\ * Corresponding author
}

Published: 18 July 2005

BMC Cancer 2005, 5:78 doi:10.1/86/147/-2407-5-78
Received: 23 November 2004

Accepted: 18 July 2005

This article is available from: http://www.biomedcentral.com/I47/-2407/5/78

(c) 2005 Di Nicolantonio et al; licensee BioMed Central Ltd.

This is an Open Access article distributed under the terms of the Creative Commons Attribution License (http://creativecommons.org/licenses/by/2.0), which permits unrestricted use, distribution, and reproduction in any medium, provided the original work is properly cited.

\begin{abstract}
Background: Tumor resistance to chemotherapy may be present at the beginning of treatment, develop during treatment, or become apparent on re-treatment of the patient. The mechanisms involved are usually inferred from experiments with cell lines, as studies in tumor-derived cells are difficult. Studies of human tumors show that cells adapt to chemotherapy, but it has been largely assumed that clonal selection leads to the resistance of recurrent tumors.

Methods: Cells derived from 47 tumors of breast, ovarian, esophageal, and colorectal origin and 16 paired esophageal biopsies were exposed to anticancer agents (cisplatin; 5-fluorouracil; epirubicin; doxorubicin; paclitaxel; irinotecan and topotecan) in short-term cell culture (6 days). Real-time quantitative PCR was used to measure up- or down-regulation of 16 different resistance/ target genes, and when tissue was available, immunohistochemistry was used to assess the protein levels.

Results: In 8/16 paired esophageal biopsies, there was an increase in the expression of multi-drug resistance gene I (MDRI) following epirubicin + cisplatin + 5-fluorouracil (ECF) chemotherapy and this was accompanied by increased expression of the MDR-I encoded protein, P-gp. Following exposure to doxorubicin in vitro, I3/14 breast carcinomas and $9 / 12$ ovarian carcinomas showed $>2$ -
\end{abstract}


fold down-regulation of topoisomerase II $\alpha$ (TOPOIl $\alpha$ ). Exposure to topotecan in vitro, resulted in $>4$-fold down-regulation of TOPOIl $\alpha$ in 6/7 colorectal tumors and 8/10 ovarian tumors.

Conclusion: This study suggests that up-regulation of resistance genes or down-regulation in target genes may occur rapidly in human solid tumors, within days of the start of treatment, and that similar changes are present in pre- and post-chemotherapy biopsy material. The molecular processes used by each tumor appear to be linked to the drug used, but there is also heterogeneity between individual tumors, even those with the same histological type, in the pattern and magnitude of response to the same drugs. Adaptation to chemotherapy may explain why prediction of resistance mechanisms is difficult on the basis of tumor type alone or individual markers, and suggests that more complex predictive methods are required to improve the response rates to chemotherapy.

\section{Background}

Tumor resistance to chemotherapy is a well-known clinical phenomenon that is now yielding its secrets to investigation at the molecular level in biopsy material. Studies in cell lines do not always correlate well with results from tumor tissue [1], which may consist largely of non-neoplastic cells that support and modify the biology of neoplastic cells. Thus it is important to validate the mechanisms important in vitro with the situation in the patient. Nevertheless, cell line studies and immunohistochemical studies of tumors suggest that resistance is a selective process: only those cells that survive a druginduced insult will re-grow.

We have previously shown development of such resistance to combination chemotherapy in tumor-derived cells from matched biopsies collected from breast cancer patients before and after administration of doxorubicincontaining chemotherapy [2]. In this study we show similar results in patients with esophageal cancer from biopsies obtained prior to and several months after chemotherapy. Two cycles of the combination of epirubicin, cisplatin and 5-FU (ECF) are given to these patients prior to resection, allowing studies to be performed with paired samples before and after chemotherapy. We have used real-time quantitative RT-PCR (qRT-PCR) and immunohistochemistry (IHC) to assess targets known to be of importance to resistance to these agents.

The mechanisms involved in resistance to chemotherapy usually involve up-regulation of resistance mechanisms, or down-regulation of target genes. Examples of the former include drug efflux pump molecules such as multidrug resistance gene $1 / \mathrm{P}$-glycoprotein (MDR1/P-gp), while the latter include topoisomerases (TOPOs), targets of drugs such as etoposide and doxorubicin. Many papers attest to the importance of clonal selection in this process: it is for instance possible to expose cell lines to low concentrations of drugs and, over time, to produce highly resistant sub-clones [3]. However, there is another potential mechanism that does not require clonal selection: cells may be able to adapt by regulation of expression of resistance or target molecules individually if they survive the initial exposure to the drug. This could be a more rapid process and would require changes in molecular expression, possibly due to epigenetic change, rather than genetic mechanisms such as mutation [4]. As a result, resistance may therefore arise rapidly following treatment with chemotherapy.

Recent studies have shown that the expression of MDR1/ P-gp is up-regulated within hours of anti-cancer drug treatment in vivo in patient samples [5-8], although this effect was not observed in all patients. We therefore wished to examine how quickly and in how many cases these resistance molecules were up-regulated in tumorderived cells from several tumor types. We have used selective short-term cell culture ( 6 days) to examine the changes in expression that occur following exposure to chemotherapy compared to medium-only control cells from the same samples. Our short-term culture system employs a serum-free medium and polypropylene 96 ' $U$ ' well microplates. This inhibits the proliferation and survival of normal cells and allows selective survival of a neoplastic cell population [9]. The short incubation period also limits the possibility of selection of clones or subpopulations in vitro. However, the presence of non-neoplastic cells for most of the incubation period allows the interaction between stromal cells and neoplastic cells, a factor that appears to be important to maintain the chemosensitivity profile [10].

\section{Methods}

\section{Patients and tissue samples for in vitro studies}

Tumor derived cells were obtained from 17 breast cancer patients (16 primaries; 1 pre-treated with mitoxantrone and paclitaxel), 13 ovarian cancer patients (all pre-treated with a cisplatin-based regimen), 10 colorectal cancer patients (all primaries) and 7 esophageal cancer patients (3 untreated; 4 treated with ECF). Cells were grown for 6 days in serum-free medium with or without drugs, before RNA extraction and further PCR analysis. 


\section{Patients and tissue samples for in vivo study}

Thirty-four esophageal adenocarcinoma biopsies, thirtytwo of which were paired samples were obtained from patients (17M:1F; median age 57 , range $42-81$ ) before and after administration of 2 cycles of ECF chemotherapy. After enzymatic digestion, tumor derived cells were centrifuged over Ficoll (Sigma Chemical Co, Poole, UK, Cat. No. 1077-1) to remove blood contaminating cells, washed in PBS, and stored in RNA later (Ambion, Huntingdon, UK) at $-80^{\circ} \mathrm{C}$ until further molecular analysis was performed. Tissue sections from these samples were stained for GST- $\pi$, MRP1, P-gp and TS. All tumor samples were removed as part of patient treatment, with consent for tissue donation and local research ethics committee approval for use of the tissue surplus to diagnostic requirements for cellular and molecular assays. Chemosensitivity data were available for 9 patients with recurrent ovarian cancer, before treatment and on relapse, though in only one case was material available from both samples for quantitative RT-PCR.

\section{Drugs}

Cisplatin, 5-fluorouracil (5-FU), epirubicin, doxorubicin, irinotecan, paclitaxel $\left(\right.$ Taxol $^{\circledR}$ ) and topotecan (Hycamp$\left.\operatorname{tin}^{\circledR}\right)$ were obtained from the pharmacy at Queen Alexandra Hospital (Portsmouth, UK). Cisplatin, 5-FU, irinotecan and paclitaxel were stored at room temperature, while all other drugs were stored at $-20^{\circ} \mathrm{C}$, as previously reported [11]. Test drug concentrations (TDC) were $10.0 \mu \mathrm{M}$ for cisplatin, $345 \mu \mathrm{M}$ for 5 -FU, $148 \mu \mathrm{M}$ for irinotecan, $15.9 \mu \mathrm{M}$ for paclitaxel, $2.5 \mu \mathrm{M}$ for doxorubicin, $0.862 \mu \mathrm{M}$ for epirubicin, and $1.64 \mu \mathrm{M}$ for topotecan. Combinations were made up by adding two or three drugs concurrently at their 200\% TDC at the beginning of the ATP-cell viability assay and diluted in a constant ratio: sequential studies were not performed.

\section{Short-term cell culture}

Briefly, tumor tissue or fluid was taken by a histopathologist or surgeon under sterile conditions, and transported to the laboratory in cell culture medium of Dulbecco's modified Eagle's medium (DMEM; Sigma Cat No. D5671) with antibiotics (100 U/ml penicillin and $100 \mu \mathrm{g} /$ ml streptomycin, Sigma, Cat No. P0781) at $4{ }^{\circ} \mathrm{C}$. Cells were obtained from solid tumors by enzymatic dissociation, usually $0.75 \mathrm{mg} / \mathrm{ml}$ collagenase (Sigma Cat No. C8051 ) overnight. Viable tumor-derived cells were purified by density centrifugation (Histopaque 1077-1, Sigma), washed, counted and resuspended to 100,000 cells $/ \mathrm{ml}$ in case of effusions or 200,000 cells/ml for solid biopsies. In the meantime 96-well polypropylene microplates (Corning-Costar, High Wycombe, UK; Cat No. 3790) were prepared with each drug/combination at six doubling dilutions in triplicate from 200\% TDC to $6.25 \%$ TDC, according to Andreotti et al. [9]. Approximately 10,000-
20,000 cells/well were added to the plates to a final volume of $200 \mu \mathrm{l} /$ well. The plates were then incubated at $37^{\circ} \mathrm{C}$ in $5 \% \mathrm{CO}_{2}$ for 6 days, after which the degree of cell inhibition was assessed by measurement of the remaining ATP in comparison with negative control (no drug, MO) and positive control (maximum inhibitor, $\mathrm{MI}$ ) rows of 12 wells each. Prior to cell lysis with an ATP-extracting reagent, an aliquot of $150 \mu \mathrm{l}$ of cell suspension were removed from each well, centrifuged, washed with phosphate buffered saline (PBS) and stored at $-80^{\circ} \mathrm{C}$ in a GTIC-containing solution (lysis buffer RA1, Macherey-Nagel, Düren, Germany; Cat. No.740961) until further molecular analysis was carried out. The RNA was subsequently extracted from aliquots that had been exposed to a drug concentration capable of inhibiting cell growth by $40-60 \%$. ATP was extracted from the remaining $50 \mu \mathrm{l}$ cell suspension and measured by light output in a microplate luminometer (Berthold Diagnostic Systems GmbH, Pforzheim, Germany) following addition of luciferin-luciferase.

\section{RNA extraction}

Cells obtained after enzymatic dissociation from endoscopic esophageal biopsies or short term cell culture were either resuspended in RNA later (Ambion, Huntingdon, UK; Cat No. 7020) or lysed with buffer RA1 and stored at $-80^{\circ} \mathrm{C}$ until RNA extraction. Total RNA was extracted from at least 50,000 cells with a commercially available kit (NucleoSpin $^{\circledast}$ RNA II mini, Macherey-Nagel; Cat No. 740955) according to the manufacturer's instructions. The protocol included a DNase digestion step to prevent carry-over of genomic DNA in further analysis.

\section{qRT-PCR}

A two-step protocol was employed. Firstly, total RNA was reverse-transcribed using the Promega reverse transcription system (Promega, Southampton, UK; Cat No. A3500) including $8 \mu \mathrm{l}$ RNA, $0.5 \mu \mathrm{g}$ random primers, 20 units of recombinant RNasin ${ }^{\circledR}$ ribonuclease inhibitor and 15 units of reverse transcriptase AMV (Promega, Cat No. M9004) to each $20 \mu \mathrm{l}$ reaction. The resulting c-DNA was amplified by qPCR on a Biorad iCycler instrument (BioRad Laboratories, Hemel Hampstead, UK). The constituents of each PCR reaction $(25 \mu \mathrm{l})$ were $1 \mu \mathrm{l}$ of cDNA (or $\mathrm{H}_{2} \mathrm{O}$ ), 200-500 nM of each primer (Table 1), $200 \mu \mathrm{M}$ each dATP, dCTP, dGTP, $400 \mu \mathrm{M}$ dUTP, 3.0-5.0 mM $\mathrm{MgCl}_{2}, 0.125$ units AMPErase ${ }^{\circledast} \mathrm{UNG}, 0.625$ units of AmpliTaq Gold DNA polymerase and $1 \times$ SYBR Green PCR buffer (all reagents were from Applied Biosystems, Warrington, UK). Product amplification was performed up to 45 PCR cycles, after uracil removal $\left(2 \mathrm{~min}\right.$ at $\left.50^{\circ} \mathrm{C}\right)$ and polymerase activation $\left(10 \mathrm{~min}\right.$ at $\left.95^{\circ} \mathrm{C}\right)$. Each two-step PCR cycle comprised denaturing ( $15 \mathrm{~s}$ at $\left.95^{\circ} \mathrm{C}\right)$, annealing, and extending $\left(1 \mathrm{~min}\right.$ at $\left.60^{\circ} \mathrm{C}\right)$. At the end of each run a final melt curve cycle (cooling to $50^{\circ} \mathrm{C}$ and then increasing stepwise $1^{\circ} \mathrm{C}$ to $95^{\circ} \mathrm{C}$ ) was performed to exclude the 
Table I: List of primers for qRT-PCR. Sequence of primers (forward and reverse) used for qRT-PCR experiments. GenBank accession numbers for each gene are indicated in brackets. The primers were designed using an old version of the software Primer 3.0, available at the following website: http://www-genome.wi.mit.edu/cgi-bin/primer/primer3.cgi/

\begin{tabular}{|c|c|c|c|c|c|}
\hline Name & Sequence 5'-3' (forward and reverse primer) & Product length & Primer nM & $\mathrm{Mg}^{2+} \mathrm{mM}$ & Reference \\
\hline \multirow[t]{2}{*}{ GAPDH* (NM_002046) } & GAA GGT GAA GGT CGG AGT C & 226 & 200 & 4 & - \\
\hline & GAA GAT GGT GAT GGG ATT TC & & 200 & & \\
\hline \multirow{2}{*}{ HPRTI* (NM_000I94) } & TCA GGC AGT ATA ATC CAA AGA TGG T & 84 & 400 & 4 & [38] \\
\hline & AGT CTG GCT TAT ATC CAA CAC TTC G & & 400 & & \\
\hline \multirow[t]{2}{*}{ PBGD* (NM_000I90) } & CTG CAC GAT CCC GAG ACT CT & 98 & 400 & 4 & [39] \\
\hline & GCT GTA TGC ACG GCT ACT GG & & 400 & & \\
\hline \multirow[t]{2}{*}{ SDHA* (NM_004I68) } & TGG GAA CAA GAG GGC ATC TG & & 400 & 4 & {$[12]$} \\
\hline & CCA CCA CTG CAT CAA ATT CAT G & & 400 & & \\
\hline \multirow[t]{2}{*}{ TBP* (X54993) } & CAC GAA CCA CGG CAC TGA TT & 89 & 400 & 4 & {$[40]$} \\
\hline & TTT TCT TGC TGC CAG TCT GGA C & & 400 & & \\
\hline \multirow[t]{2}{*}{ BCRP (AF09895I) } & CAC AAC CAT TGC ATC TTG GC & 74 & 400 & 4 & {$[4 I]$} \\
\hline & GCT GCA AAG CCG TAA ATC CA & & 400 & & \\
\hline \multirow{2}{*}{ DPD (NM_000I I0) } & CCA AAG GCA GTA AAG CAG GAA & 66 & 400 & 4 & [42] \\
\hline & TCA CGA CTC CCC GTA TCG A & & 400 & & \\
\hline \multirow[t]{2}{*}{ EGFR (NM_005228) } & TGG TCA AGT GCT GGA TGA TAG A & 156 & 400 & 4 & - \\
\hline & GGT AGA AGT TGG AGT CTG TAG GA & & 400 & & \\
\hline \multirow[t]{2}{*}{ ERCC-I (NM_00I983) } & GGG AAT TTG GCG ACG TAA TTC & 71 & 400 & 3 & [43] \\
\hline & GCG GAG GCT GAG GAA CAG & & 400 & & \\
\hline \multirow{2}{*}{ GST- $\pi$ (NM_000852) } & CGG AGA CCT CAC CCT GTA & 169 & 400 & 5 & - \\
\hline & CGC CTC ATA GTT GGT GTA GA & & 400 & & \\
\hline \multirow[t]{2}{*}{ MDRI (AF0I6535) } & TGG TTC AGG TGG CTC TGG AT & 72 & 300 & 4 & [44] \\
\hline & CTG TAG ACA AAC GAT GAG CTA TCA CA & & 300 & & \\
\hline \multirow[t]{2}{*}{ MLH-I (NM_000249) } & GGC ACA GCA TCA AAC CAA GT & 147 & 400 & 4 & - \\
\hline & GCA AGC ATG GCA AGG TCA A & & 400 & & \\
\hline \multirow[t]{2}{*}{ MRPI (L05628) } & CAA TGC TGT GAT GGC GAT G & 70 & 400 & 4 & [39] \\
\hline & GAT CCG ATT GTC TTT GCT CTT CA & & 400 & & \\
\hline \multirow[t]{2}{*}{ MRP2 (NM_000392) } & TGC AGC CTC CAT AAC CAT GAG & 80 & 400 & 3 & {$[45]$} \\
\hline & GAT GCC TGC CAT TGG ACC TA & & 400 & & \\
\hline \multirow[t]{2}{*}{ MT-II (NM_005953) } & GAT CCC AAC TGC TCC TGC & 127 & 400 & 4 & - \\
\hline & ACT TGG CAC AGC CCA CAG & & 400 & & \\
\hline \multirow[t]{2}{*}{ MVP (NM_0I7458) } & CAG CTG GCC ATC GAG ATC A & 68 & 400 & 4 & [39] \\
\hline & TCC AGT CTC TGA GCC TCA TGC & & 400 & & \\
\hline \multirow[t]{2}{*}{ TP (NM_00I953) } & CCT TGG ATA AGC TGG AGT CT & 107 & 400 & 4 & - \\
\hline & СCT АCT CTG ACC CAC GAT AC & & 400 & & \\
\hline \multirow[t]{2}{*}{ TS (NM_00I07I) } & CCA GAG ATC GGG AGA CAT GG & 66 & 400 & 4 & - \\
\hline & TAC GTG AGC AGG GCG TAG CT & & 400 & & \\
\hline \multirow[t]{2}{*}{ TOPO I (J03250) } & CTC CAC AAC GAT TCC CAG AT & 149 & 400 & 3 & - \\
\hline & TTA TGT TCA CTG TTG CTA TGC TT & & 400 & & \\
\hline \multirow[t]{2}{*}{ TOPO II $\alpha$ (NM_00I067) } & GTA ATT TTG ATG TCC CTC CAC GA & 223 & 400 & 3 & - \\
\hline & TCA AGG TCT GAC ACG ACA CTT & & 400 & & \\
\hline \multirow{2}{*}{ TOPO II (NM_00I068) } & GCA GCC GAA AGA CCT AAA TA & 85 & 400 & 3 & - \\
\hline & AAT CAT TAT TGT CAT CAT CAT CAT C & & 400 & & \\
\hline
\end{tabular}

(N.B. Where primer sequences have been taken from references the PCR conditions have been further optimised compared to the original reference.)

* Housekeeping genes.

presence of primer-dimer artefacts. At least 3 housekeeping genes were used for each experiment chosen from the following: glyceraldehyde-3 phosphate dehydrogenase (GAPDH), hypoxanthine phosphoribosyltransferase 1 (HPRT1), human porphobilinogen deaminase (PBGD), succinate dehydrogenase complex-subunit A (SDHA) and
TATA box binding protein (TBP). The internal reference genes were selected due to their relative low abundance in normal tissue [12]. The housekeeping genes were amplified parallel to the target genes in separate wells. When possible, primer sequences (Table 1) were chosen to span exon boundaries to the following targets: breast cancer 
Table 2: List of antibodies used for immunohistochemical studies.

\begin{tabular}{|c|c|c|c|c|c|c|}
\hline Antibody & Pre-Treatment & Dilution & Incubation & Cat No. & Source & Control Tissue \\
\hline $\begin{array}{l}\text { Glutathione S-Transferase pi } \\
\text { GST- } \pi \text { (polyclonal) }\end{array}$ & None & $1: 150$ & $30 \min \mathrm{RT}$ & PU249-UP & $\begin{array}{l}\text { BioGenex (Distributor: } \\
\text { Menarini Diagnostics, } \\
\text { Wokingham, UK) }\end{array}$ & Breast Ca \\
\hline $\begin{array}{l}\text { P-glycoprotein (MDR-I) } \\
\text { (Clone JSB-I) }\end{array}$ & $\begin{array}{l}\text { Pressure Cook } 2 \\
\min \mathrm{pH} 6.0\end{array}$ & $1: 100$ & Overnight $4^{\circ} \mathrm{C}$ & NCL-JSBI & $\begin{array}{l}\text { Novo Castra Newcastle- } \\
\text { upon-Tyne, UK }\end{array}$ & Kidney \\
\hline $\begin{array}{l}\text { Multidrug Resistant-Related } \\
\text { Protein (MRP) (Clone } \\
\text { MRPm6, specific for MRP-I) }\end{array}$ & $\begin{array}{l}\text { Pressure Cook } 2 \\
\text { min } \mathrm{pH} 7.0\end{array}$ & $1: 30$ & $30 \min \mathrm{RT}$ & MAB4II22 & $\begin{array}{l}\text { Chemicon International } \\
\text { Chandlers Ford, UK }\end{array}$ & Kidney \\
\hline $\begin{array}{l}\text { Thymidylate Synthase TS } \\
\text { (Clone TS 106) }\end{array}$ & $\begin{array}{l}\text { Pressure Cook } 2 \\
\min \mathrm{pH} 6.0\end{array}$ & $\mathrm{I}: 20$ & $30 \min \mathrm{RT}$ & MS47IP & $\begin{array}{l}\text { Neo Markers (Distributor: } \\
\text { Lab Vision, Newmarket, UK) }\end{array}$ & Colon $\mathrm{Ca}$ \\
\hline
\end{tabular}

When sections required microwaving a Matsui MIIOM microwave was used at $800 \mathrm{~W}$ power. Pressure cooking was performed with a Tefal Clipso Pressure Cooker using $70 \mathrm{P}$ power.

resistance protein (BCRP), dihydropyrimidine dehydrogenase (DPD), epidermal growth factor receptor (EGFR), excision repair cross-complementing 1 (ERCC1) gene, glutathione-S-transferase isoform $\pi$ (GST- $\pi$ ), multi-drug resistance gene 1 (MDR1), MLH1, multi-drug resistance related protein 1 (MRP1), multi-drug resistance related protein 2 (MRP2), metallothionein (MT), major vault protein (MVP), thymidine phosphorylase (TP), thymidylate synthase (TS), topoisomerase I (TOPO I), topoisomerase II $\alpha$ and $\beta$ (TOPO II $\alpha$ and TOPO II $\beta$ ). Each amplicon was amplified in a separate reaction to prevent competition among multiple sets of primers. A positive control (pooled c-DNA from a variety of human tumors, including breast, ovarian, colorectal and esophageal carcinoma) and negative controls with no template and RTnegative as template were added in every experiment. All assays were run in triplicate. Validation experiments were run to show that the efficiencies of the target and reference genes amplifications were approximately equal, and in the range $95-105 \%$. The PCR cycle number that generated the first fluorescence signal above a threshold (threshold cycle, $\mathrm{Ct} ; 10$ standard deviations above the mean fluorescence generated during the baseline cycles) was determined, and a comparative $\mathrm{Ct}$ method was then used to measure relative gene expression [13]. The following formula was used to calculate the relative amount of the tran-

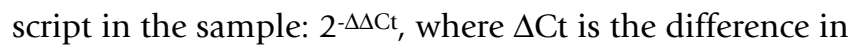
$\mathrm{Ct}$ between the gene of interest and the mean of the at least two reference genes, and $\Delta \Delta \mathrm{Ct}=\Delta \mathrm{Ct}$ of drug nonexposed cells - $\Delta \mathrm{Ct}$ of drug-exposed cells, for the ex-vivo experiments, or $\Delta \Delta \mathrm{Ct}=\Delta \mathrm{Ct}$ of pre-chemotherapy sample - $\Delta \mathrm{Ct}$ of post-chemotherapy sample, for matched tumor biopsies.

\section{Immunohistochemistry}

The monoclonal antibodies (Abs) for GST- $\pi$, MRP1, Pg-p, and TP (Table 2) were detected using the Chemicon IHC Select $^{\mathrm{TM}}-$ Immuno Peroxidase secondary detection system
(Chemicon International, Chandlers Ford, Southampton, UK, Cat\# Det-HP1000) and stained with 3,3' diaminobenzidine (DAB; HD Supplies, Aylesbury, UK, Cat. 4170) on a Dako Autostainer instrument (Dako, Ely, UK). Positive and negative controls were included with each run. Volumes of $50 \mu \mathrm{l}$ avidin/ml goat serum and $50 \mu \mathrm{l}$ biotin/ml primary Ab were used to block endogenous avidin binding. The slides were counterstained with Gills Haematoxylin, dehydrated and cleared using the Leica ${ }^{\circ} \mathrm{XL}$ slide staining machine and mounted in Styrolite ${ }^{\circledast}$ mounting medium (BDH, Poole, Dorset, UK; Cat No. 361704Y).

\section{Data analysis}

The luminometer readings obtained from the ATP-TCA were entered into an Excel 2000 spreadsheet (Microsoft) which calculated the percentage of cell inhibition for each drug concentration according to the previous published formula: 1 - [(Test - MI)/(MO - MI) ${ }^{*} 100$ [9]. For each drug-response curve, the $50 \%$ inhibitory concentration (IC50) and the 90\% inhibitory concentration (IC90) were also calculated as previously described [14].

Assessment of slides was done using the H-score. Staining intensity (none, 0 points; weak, 1 point; moderate, 2 points; strong, 3 points) and percentage of positive tumor cells were multiplied to achieve a score between 0 and 300. A H-score of 100 or more was regarded as positive and results less than 100 were regarded as negative. The correlation coefficients were calculated by the method of the least squares, and the correlation between the IC90 and IC50 values and immunohistochemistry indices was assessed using univariate linear regression (Statsdirect, Sale, UK).

Non-parametric statistical methods were used. The calculated and descriptive data were entered into an Access 2000 database (Microsoft) and analysed using a Wilcoxon two-tailed paired rank sum test for paired data or the 
Mann-Whitney U test for unpaired data, as appropriate (Statsdirect). IC50 and IC90 values for each compound were correlated to the relative mRNA levels of target genes using Spearman's rank correlation coefficient and multivariate analysis. On statistical advice, we chose not to use a Bonferroni's correction, but it should be noted that some technically statistically significant results could have arisen by chance.

\section{Results \\ Chemotherapy-induced changes in mRNA levels in biopsy material}

Figures 1a-e illustrate changes to IC50 $\mu \mathrm{M}$ values in preand post chemotherapy ovarian tumor-derived cells tested with a variety of chemotherapeutic agents. There is a general increase in resistance to doxorubicin when anthracycline-based regimens (mitoxantrone + paclitaxel or liposomal doxorubicin) are administered to ovarian cancer patients (Fig. 1a). We observed little cross-resistance for mitoxantrone, topotecan, paclitaxel, and cisplatin following anthracycline-based chemotherapy (Fig. 1b-e), [15], although some patients do show alteration of sensitivity to other agents. Similar changes can be seen in breast cancer biopsies before and after administration of a chemotherapy regimen [2]. The increase in resistance to doxorubicin shown in Figure 1a was accompanied by changes in drug resistance gene expression. Figure $1 \mathrm{f} \mathrm{high-}$ lights such up-regulation of MDR1 and breast cancer resistance protein (BCRP) observed in ovarian-tumor derived cells from a single patient.

Membrane proteins such as MDR1/P-gp, multi-drug resistance protein 1 (MRP1) and major vault protein (MVP) have been demonstrated to confer resistance to epirubicin by pumping the cytotoxic drug out of cells [16]. Paired esophageal samples were obtained from the same six patients both before and after chemotherapy; in all 6 biopsy pairs (Table 3), there was an increase of the mRNA levels of MDR1 following ECF chemotherapy (Fig. 2a). In a larger series of 20 esophageal samples (including those that did not have a paired biopsy), divided in two groups according to the patients' exposure to treatment, there was a 5-fold increase in MDR1 expression in the post-chemotherapy group (median expression index 0.07 pre- and 0.37 post-chemotherapy, $\mathrm{p}<0.0001$, Mann-Whitney non-parametric unpaired $U$ test). The paired samples from patients before and after ECF chemotherapy also showed a trend towards increased expression of MRP1 and MVP (Table 3), with three tumors showing concomitant up-regulation of both genes. Furthermore, the increased expression of MRP1 paralleled that of glutathione-S-transferase isoform $\pi$ (GST- $\pi$ ) in 2 of these 3 samples, consistent with the mechanism of detoxification of MRP1 that involves transport of glutathione-conjugated molecules [17].
We then determined the relative mRNA levels of enzymes that have previously been correlated with 5-FU sensitivity: dihydropyrimidine dehydrogenase (DPD), thymidine phosphorylase (TP) and thymidylate synthase (TS) [18]. No significant difference was found for these 3 genes when we compared their expression pre- and post-chemotherapy in unpaired samples (Table 3). However, we found a modest increase of TS expression in 5/6 paired samples (Fig. 2b), 3 of which also showed a concomitant decrease in TP levels. One sample showed a paradoxical decrease in TS, indicating some heterogeneity. Although the sample size is small, the trend of increased TS levels in ECF exposed tumors is consistent with a number of previous reports that demonstrated an acute induction of TS expression in cell lines, animal models and human tumors following 5-FU treatment [18,19].

It should be noted that these qRT-PCR results were all obtained from samples that included normal cells present in the tumor as well as neoplastic cells, and could be affected by changes in normal cells as well as malignant cells.

\section{Chemotherapy-induced changes in protein levels in biopsy material}

IHC was performed on 16 paired esophageal biopsies: qRT-PCR data were obtained for four of these pairs. Overall, we were able to confirm an increased expression of the MDR-1 encoded protein, P-gp (Table 4), in 8/16 paired tumor samples obtained from patients who had been exposed to ECF chemotherapy. TS positivity (Table 4) was found in 10/16 samples obtained before treatment and $10 / 16$ post-chemotherapy specimens; in this instance the modest induction of TS seen at the mRNA level did not reflect an increase in protein level (data not shown). We found GST- $\pi$ (Table 4 ) positivity in 5/16 pre-chemotherapy biopsies. In the post-chemotherapy specimens we detected strong expression of GST- $\pi$ in all but one of the samples. In one case that had been negative at diagnosis we measured a marginal increase of mRNA levels with qRT-PCR. A total of $13 / 16$ pre- and 12/16 post-chemotherapy biopsies were found to be positive for MRP1 (Table 4). Overall, these data show little correlation between the mRNA and the degree of expression of protein levels determined by IHC. Confounding factors may be the presence of non-cancerous cells as mentioned above, but also the nature of IHC, which is at best a semiquantitative technique.

\section{Changes in short-term cell culture}

Of the 47 solid tumor samples studied in short-term cultures, 7 were esophago-gastric, 17 were breast carcinomas, 13 were ovarian carcinomas and 10 were colorectal tumors. A total of 93 experiments were performed, as in 
a)

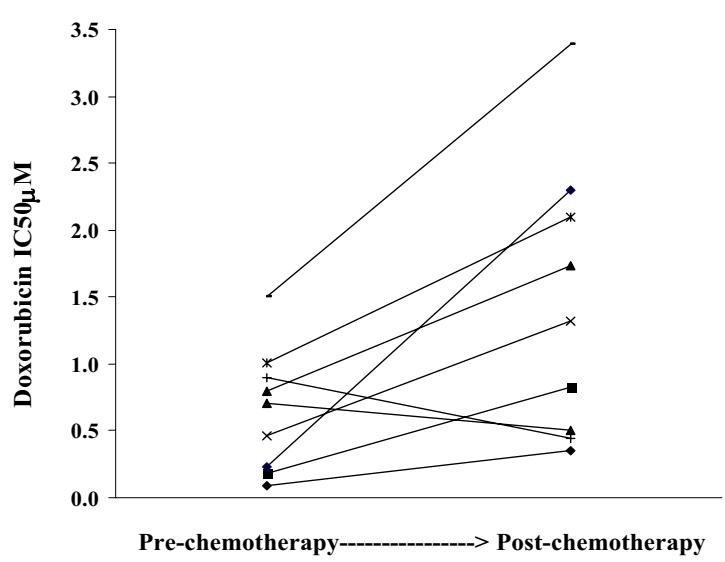

c)

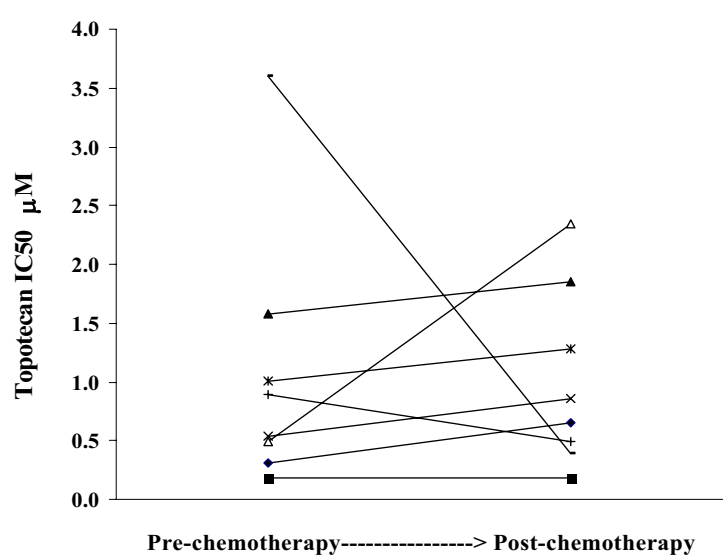

e)

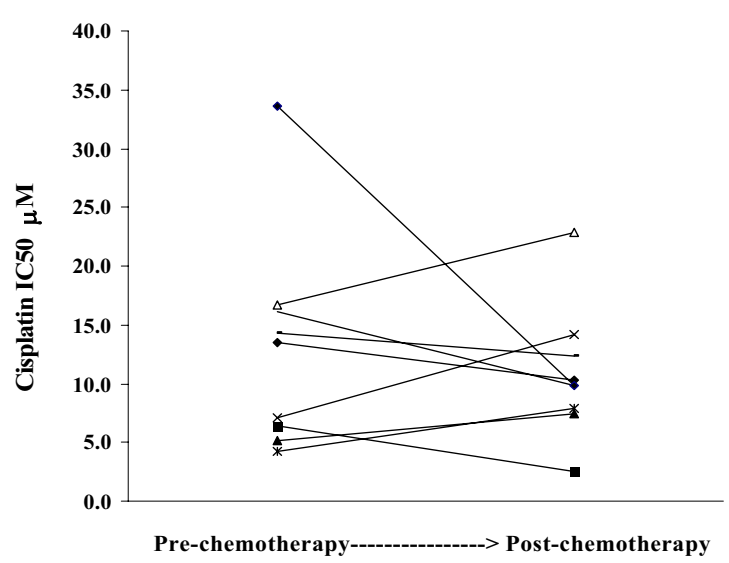

b)

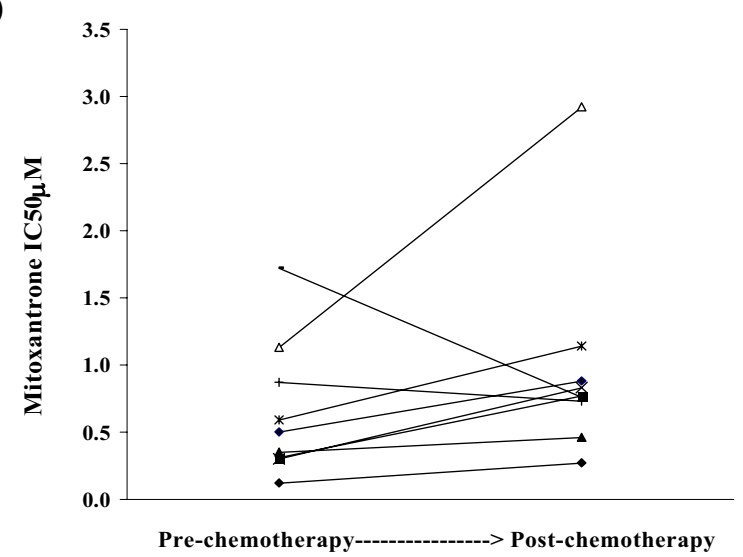

d)

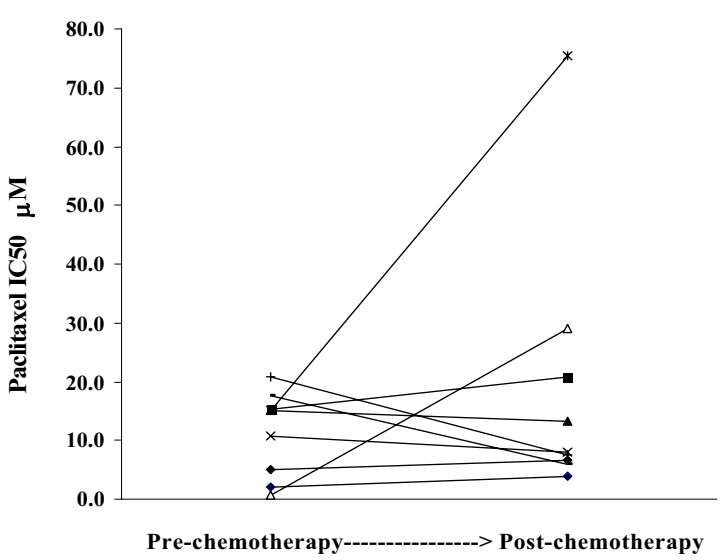

f)

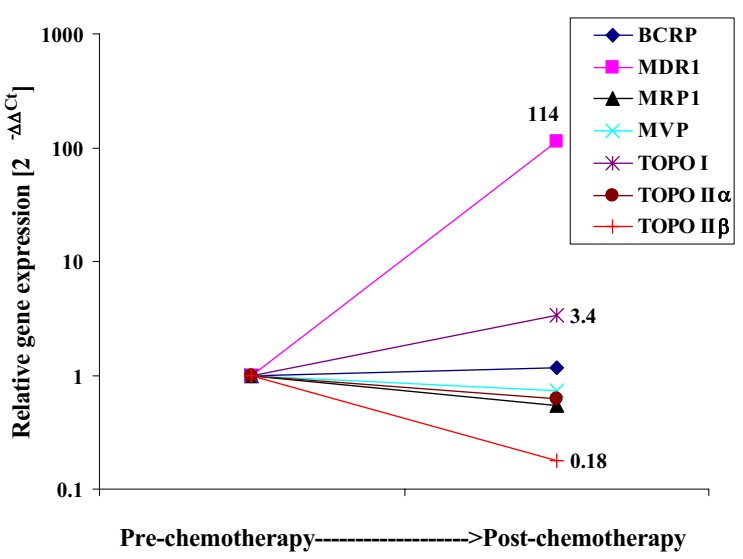

Figure I

Changes due to chemotherapy in biopsies taken before and after chemotherapy. Cytotoxicity of a) doxorubicin; b) mitoxantrone; c) topotecan; d) paclitaxel and e) cisplatin (expressed as IC50 $\mu \mathrm{M}$ ) in paired samples obtained from ovarian cancer patients before and after they were treated with an anthracycline containing regimen (paclitaxel+mitoxantrone $n=7$; liposomal doxorubicin $n=2$ ). Each line represents an individual patient. (f) Gene expression changes pre- and post-treatment (paclitaxel plus mitoxantrone chemotherapy) in one patient were analysed by qRT-PCR following in vitro exposure to doxorubicin. 
Table 3: Relative expression of mRNA levels in esophageal samples obtained from patients before and after chemotherapy (median values). The last 2 columns on the right represent values for the 12 paired biopsies. The $p$ values have been calculated using non parametric statistics, and in detail the Mann Whitney $U$ test for unpaired samples, and the Wilcoxon matched pairs test for paired samples.

\begin{tabular}{|c|c|c|c|c|c|c|}
\hline \multirow[b]{2}{*}{ Target gene } & \multicolumn{2}{|c|}{ All esophageal samples } & \multirow[b]{2}{*}{$\mathbf{p}$} & \multicolumn{2}{|c|}{ Paired esophageal samples } & \multirow[b]{2}{*}{$\mathbf{p}$} \\
\hline & Pre-chemo $n=13$ & Post-chemo $n=6$ & & Pre-chemo $n=6$ & Post-chemo $n=6$ & \\
\hline DPD & 0.71 & 1.09 & 0.4117 & 0.68 & 1.09 & 0.3750 \\
\hline GST $-\pi$ & 4.39 & 0.88 & 0.1969 & 1.61 & 1.85 & 0.8438 \\
\hline MDRI & 0.07 & 0.37 & $<0.0001$ & 0.11 & 0.43 & 0.0313 \\
\hline MRPI & 4.81 & 10.60 & 0.1624 & 4.58 & 10.77 & 0.4375 \\
\hline MT II & 36.35 & 23.43 & 0.5846 & 12.49 & 24.12 & 0.8438 \\
\hline MVP & 6.61 & 8.57 & 0.6544 & 6.39 & 9.11 & 0.5625 \\
\hline TP & 4.21 & 2.58 & 0.2326 & 3.56 & 3.01 & $>0.999$ \\
\hline TS & 1.11 & 2.43 & 0.1851 & 1.27 & 2.27 & 0.4375 \\
\hline
\end{tabular}

most cases the same sample was treated with 2 or more drugs.

\section{Doxorubicin effects in short-term cell culture}

In the first instance, we decided to study the effects of anthracycline exposure for 6 days on tumour-derived cells. Our in vitro experiments showed a significant downregulation of TOPO II $\alpha$; its median levels decreased from 0.546 (range $0.005-1.782$ ) to 0.017 (range $0.0004-$ $0.595)$ units in a group of 14 breast samples $(\mathrm{p}<0.0001$, Wilcoxon matched pairs test) and from 1.491 (range $0.080-6.884$ ) to 0.089 (range 0.003-3.605) units in the ovarian cancer subgroup ( $\mathrm{p}<0.0015$, Wilcoxon matched pairs test). The down-regulation of TOPO II $\alpha$ levels was greater than 2-fold in 13/14 breast samples and in 9/12 ovarian samples (Fig. 3a). It has been suggested that cancer cells can concomitantly down-regulate TOPO II $\alpha$ and up-regulate TOPO I in response to treatment with topoisomerase II inhibitors [20]. In our series we noted a general trend of diminished levels of TOPO I, particularly in the ovarian subgroup (Fig 3b). It is possible that doxorubicin exposure resulted in quiescence of cells which were not killed, and which would not therefore require higher levels of TOPO I, or that doxorubicin may also partly inhibit TOPO I, as suggested by a previous study [21].

We observed a significant up-regulation of MRP-1 ( $\mathrm{p}<$ 0.0001, Wilcoxon matched pairs test; Fig. 3c) and of MVP ( $p<0.0023$, Wilcoxon; Table 5) in the breast cancer subgroup. The same effect was not found in the ovarian cancer group, in which the levels of MRP-1 and MVP increased over 0.5 fold in only $4 / 12$ and 3/12 samples, respectively (Table 5). No significant changes were found in the expression of MDR-1 and BCRP, although it should be noted that there was substantial heterogeneity among individual tumors (Table 5). For example, we measured a greater than 2-fold increase of MDR-1 levels in 2/12 ovarian samples (none of whom had received a MDR-1 pumped chemotherapeutic agent before), and a significant up-regulation of BCRP in 3/12 ovarian samples.

\section{Topoisomerase I inhibitors effects in short-term cell culture}

Subsequently we looked at the effect of 2-camptothecin derivatives, irinotecan and topotecan, on colorectal and ovarian tumor cells, respectively (Table 6). As both compounds act by TOPO I inhibition, we firstly measured the levels of their target enzyme. We noted a trend towards down-regulation of TOPO I in treated cells: exposure to irinotecan decreased TOPO I levels $>2$-fold in 3/7 colorectal tumors, while topotecan caused down-regulation in $4 /$ 10 ovarian samples (Fig. 3d). The decrease of TOPO I was accompanied by a concomitant reduction of TOPO II $\alpha$ expression, which was particularly pronounced ( $>4$-fold) in $6 / 7$ colorectal tumors and $8 / 10$ ovarian tumors (Fig. $3 e)$.

No significant changes were observed in the expression of the drug efflux molecules, MDR-1, BCRP and MRP-1 (Table 6), though, as in the case of doxorubicin, considerable heterogeneity was noted. We observed an increase of BCRP levels after irinotecan or topotecan exposure in 2/7 colorectal samples and 3/9 ovarian samples.

Amongst the genes implicated in DNA repair (Table 6), the modest down-regulation of MLH1 by topotecan exposure was not found statistically significant, although it was noted in 7/10 ovarian samples. Up-regulation of ERCC1 expression was found in all 10 ovarian cancer samples exposed to topotecan ( $\mathrm{p}<0.002$, Wilcoxon), and in all 7 colorectal specimens treated with irinotecan, although in this group the increase was modest ( $\mathrm{p}=0.016$, Wilcoxon). 
a)

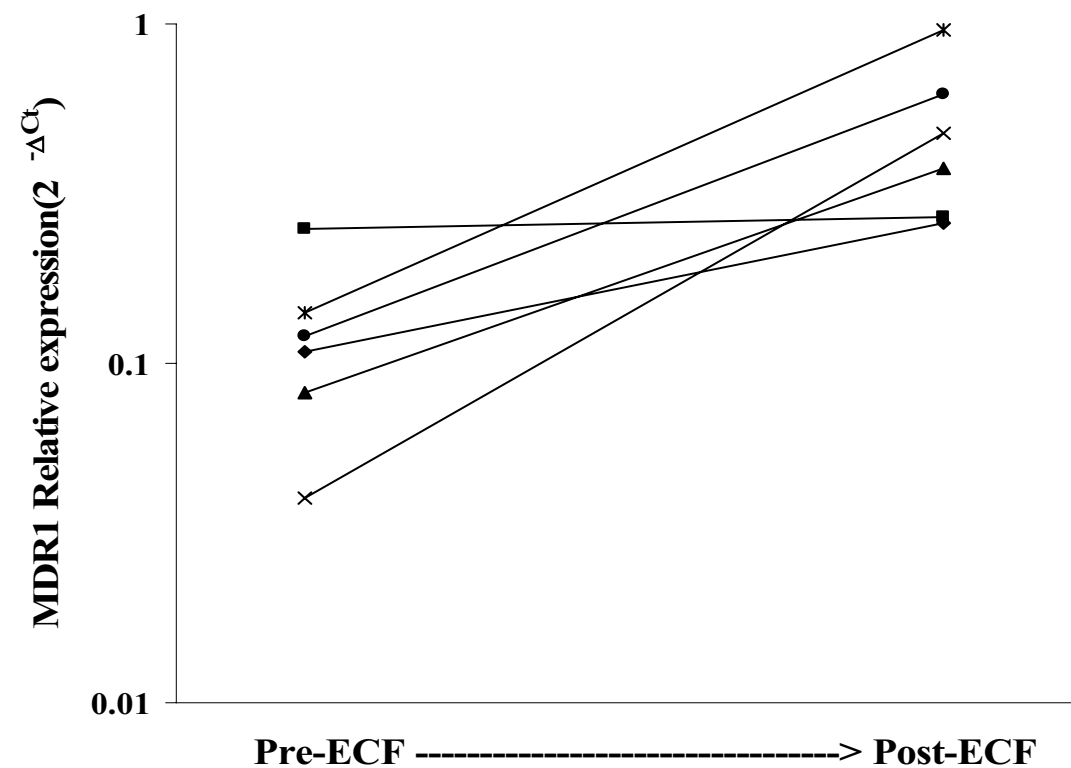

b)

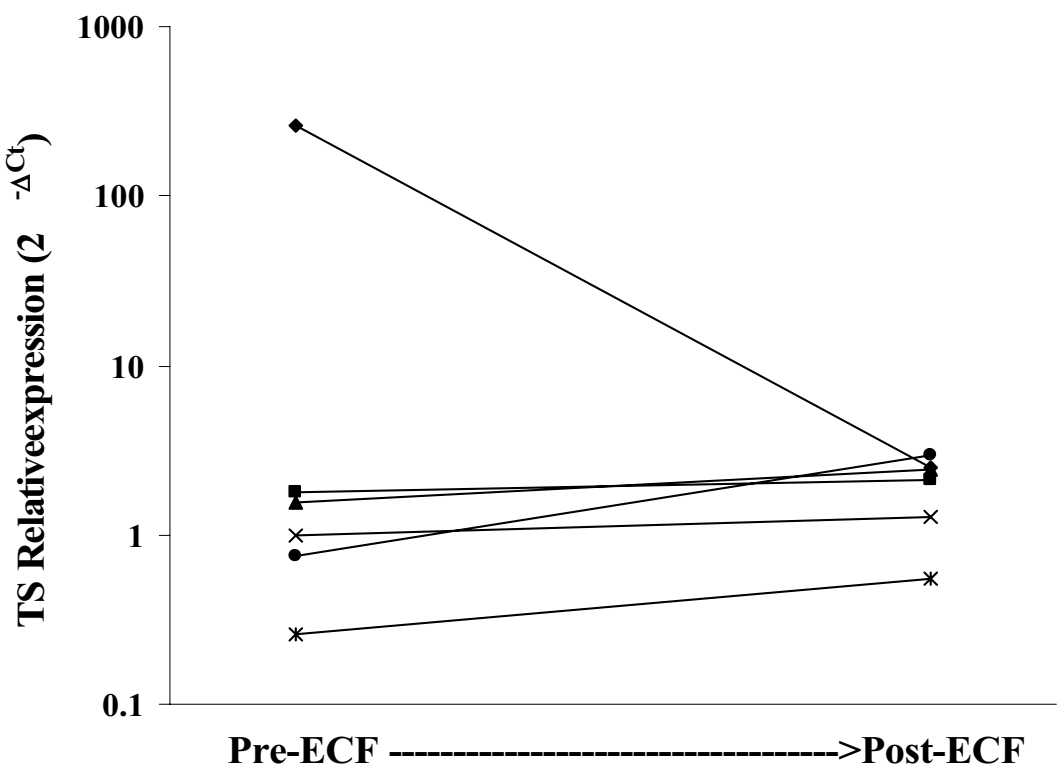

\section{Figure 2}

Changes in relative gene expression in 6 paired esophageal tumor biopsies. a) Changes in MDRI relative gene expression and b) changes in TS relative gene expression. Each dot represents the relative mRNA level for an individual tumor, measured before and after ECF chemotherapy. 
Table 4: Median expression (range in brackets) of protein levels in paired esophageal samples $(n=16)$ obtained from patients before and after chemotherapy. Slides were assessed using the $\mathrm{H}$-score. A H-score of 100 or more was regarded as positive and below 100 was regarded as negative.

\begin{tabular}{lcc}
\hline Antibody & Pre-chemotherapy & Post-chemotherapy \\
\hline GST- $\pi$ & $35(0-300)$ & $200(70-300)$ \\
P-gP & $45(0-300)$ & $100(0-300)$ \\
MRP & $100(0-200)$ & $100(10-200)$ \\
TS & $120(0-300)$ & $100(0-300)$
\end{tabular}
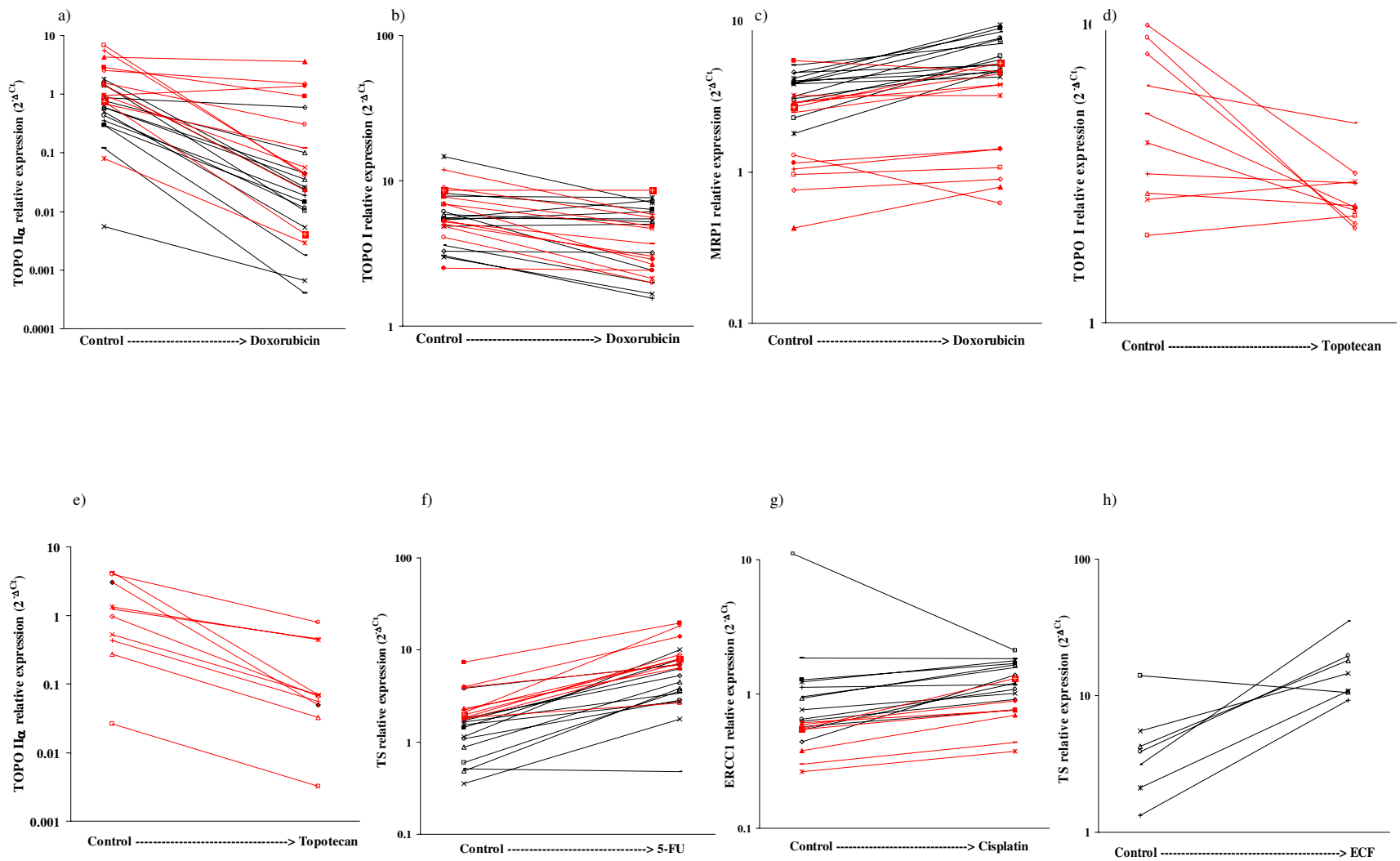

\section{Figure 3}

Changes in relative expression of putative chemoresistance genes in tumor-derived cells. Each dot represents the relative mRNA level for an individual sample, measured after in vitro drug exposure compared with untreated control cells. (a) TOPO Il $\alpha$ expression in breast (black lines) and ovarian (red lines) tumor cells after doxorubicin exposure. (b) TOPO I expression in breast (black lines) and ovarian (red lines) tumor cells after doxorubicin exposure. (c) MRPI expression in breast (black lines) and ovarian (red lines) tumor cells after doxorubicin exposure. (d) TOPO I expression in ovarian tumor cells after topotecan exposure. (e) TOPO Il $\alpha$ expression in ovarian tumor cells after topotecan exposure. (f) TS expression in breast (red lines) and colorectal (black lines) tumor cells after 5-FU exposure. (g) ERCCI expression in breast (black lines) and ovarian (red lines) tumor cells after cisplatin exposure. (h) TS expression in esophageal tumor cells after ECF exposure. The numerical data for these graphs is summarized in Tables 5-8. 
Table 5: Relative expression of mRNA levels in tumor samples after ex vivo exposure to doxorubicin. The IC $_{50}$ concentrations for the samples tested are shown for each drug (median and range). The p values have been calculated using non-parametric statistics, in detail the Wilcoxon matched pairs test. On statistical advice, we chose not to use a Bonferroni's correction, but it should be noted that some technically statistically significant results could have arisen by chance.

\begin{tabular}{|c|c|c|c|c|c|c|c|c|}
\hline \multirow[b]{2}{*}{ Target gene } & \multicolumn{4}{|c|}{ Breast samples } & \multicolumn{4}{|c|}{ Ovarian samples } \\
\hline & $\mathbf{n}$ & Control & $\begin{array}{c}\text { Doxorubicin } \mathrm{IC}_{50}=0.828 \mu \mathrm{M} \\
(0.569-1.16)\end{array}$ & $\mathbf{p}$ & $\mathbf{n}$ & Control & $\begin{array}{c}\text { Doxorubicin } \mathrm{IC}_{50}=1.34 \mu \mathrm{M} \\
(0.310-17.7)\end{array}$ & $\mathbf{p}$ \\
\hline BCRP & 14 & 0.039 & 0.044 & 0.8077 & 12 & 0.010 & 0.027 & 0.042 \\
\hline ERCCI & 14 & 0.711 & 0.826 & 0.2412 & 11 & 0.440 & 0.506 & 0.4922 \\
\hline MDRI & 14 & 0.069 & 0.056 & 0.0494 & 12 & 0.005 & 0.005 & 0.2036 \\
\hline MRP I & 14 & 3.886 & 5.692 & $<0.0001$ & 12 & 1.890 & 2.321 & 0.083 \\
\hline MVP & 14 & 4.990 & 6.925 & 0.0023 & 12 & 2.251 & 2.687 & 0.042 \\
\hline TOPO I & 14 & 5.464 & 5.128 & 0.0419 & 12 & 6.112 & 3.360 & 0.001 \\
\hline TOPO II $\alpha$ & 14 & 0.546 & 0.017 & $<0.0001$ & 12 & 1.491 & 0.089 & 0.0015 \\
\hline TOPO II & 14 & 6.617 & 6.461 & 0.0785 & 12 & 5.907 & 5.252 & 0.0322 \\
\hline
\end{tabular}

Table 6: Relative expression of mRNA levels in tumor samples after ex vivo exposure to topotecan and irinotecan. The IC $_{50}$ concentrations for the samples tested are shown for each drug (median and range). The $p$ values have been calculated using nonparametric statistics, in detail the Wilcoxon matched pairs test. On statistical advice, we chose not to use a Bonferroni's correction, but it should be noted that some technically statistically significant results could have arisen by chance.

\begin{tabular}{|c|c|c|c|c|c|c|c|c|}
\hline \multirow[b]{2}{*}{ Target gene } & \multicolumn{4}{|c|}{ Ovarian samples } & \multicolumn{4}{|c|}{ Colorectal samples } \\
\hline & $\mathbf{n}$ & Control & $\begin{array}{c}\text { Topotecan } I C_{50}=0.754 \mu \mathrm{M} \\
(0.164-4.82)\end{array}$ & $\mathbf{p}$ & $\mathbf{n}$ & Control & $\begin{array}{c}\text { Irinotecan } I C_{50}=55.4 \mu \mathrm{M} \\
(29.5-100)\end{array}$ & $\mathbf{p}$ \\
\hline BCRP & 9 & 0.0156 & 0.0125 & $>0.999$ & 7 & 0.0354 & 0.0515 & 0.6875 \\
\hline COX-2 & 10 & 0.253 & 0.475 & 0.7695 & 7 & 105.17 & 38.49 & 0.0156 \\
\hline EGFR & 10 & 0.470 & 0.163 & 0.0039 & - & - & - & - \\
\hline ERCCI & 10 & 0.252 & 0.399 & 0.002 & 7 & 1.403 & 2.469 & 0.0156 \\
\hline MDR I & 9 & 0.0090 & 0.0034 & 0.5703 & 7 & 0.2253 & 0.2938 & $>0.999$ \\
\hline MLHI & 10 & 0.263 & 0.2268 & $0.037 I$ & - & - & - & - \\
\hline MRPI & - & - & - & - & 7 & 5.132 & 3.775 & 0.0156 \\
\hline TOPO I & 10 & 4.490 & 2.448 & $0.037 I$ & 7 & 1.468 & 1.119 & 0.1094 \\
\hline TOPO II $\alpha$ & 10 & 1.093 & 0.0670 & 0.002 & 6 & 0.2847 & 0.0733 & 0.2188 \\
\hline TOPO I $\beta$ & - & - & - & - & 7 & 0.7405 & 0.5058 & 0.0313 \\
\hline
\end{tabular}

Finally, we looked at EGFR as a marker of tumor growth and progression. After topotecan exposure we found a decrease (more than 2-fold) in the expression of this growth factor in $9 / 10$ ovarian samples (Table 6 ), with the median levels decreasing from 0.470 to 0.163 units $(\mathrm{p}<$ 0.0039, Wilcoxon).

\section{5-FU effects in short-term cell culture}

Preliminary data obtained from 2 esophageal biopsies indicated an increase of TS levels following 5-FU treatment. Subsequent in vitro experiments performed on material derived from 10 colorectal tumor samples and 13 breast tumor samples confirmed the expected increase of
TS levels (Table 7) in the samples exposed to 5-FU ( $\mathrm{p}<$ 0.0001 , Wilcoxon; Fig. 3f). The results indicated a general trend towards DPD down-regulation in the cells that had been exposed to 5-FU in vitro, though this effect was modest in most cases and we observed a greater than 2 fold decrease in only $7 / 13$ breast samples and 2/10 colorectal samples.

\section{Cisplatin effects in short-term cell culture}

We examined the mRNA expression levels of genes previously highlighted as important in cisplatin resistance in tumor-derived cells from 13 breast and 7 ovarian tumors (Table 8). Up-regulation of the nucleoside excision repair 
Table 7: Relative expression of mRNA levels in tumor samples after ex vivo exposure to $5 \mathrm{FU}$. The IC $\mathrm{C}_{50}$ concentrations for the samples tested are shown for each drug (median and range). The $p$ values have been calculated using non-parametric statistics, in detail the Wilcoxon matched pairs test. On statistical advice, we chose not to use a Bonferroni's correction, but it should be noted that some technically statistically significant results could have arisen by chance.

\begin{tabular}{|c|c|c|c|c|c|c|c|c|}
\hline \multirow[b]{2}{*}{ Target gene } & \multicolumn{4}{|c|}{ Breast samples $I_{50}=200 \mu \mathrm{M}(86.5-363)$} & \multicolumn{4}{|c|}{ Colorectal samples $I_{50}=I I 2 \mu \mathrm{M}(|3.8-3| I)$} \\
\hline & $\mathbf{n}$ & Control & 5-FU & $\mathbf{p}$ & $\mathbf{n}$ & Control & 5-FU & $\mathbf{p}$ \\
\hline DPD & 13 & 1.289 & 0.494 & 0.0012 & 10 & 0.503 & 0.448 & 0.4922 \\
\hline TP & 13 & 8.876 & 10.928 & 0.6848 & 10 & 4.616 & 5.963 & 0.084 \\
\hline TS & 13 & 1.136 & 3.819 & 0.0005 & 10 & 2.157 & 7.954 & 0.002 \\
\hline
\end{tabular}

Table 8: Relative expression of $\mathrm{mRNA}$ levels in tumor samples after ex vivo exposure to cisplatin. The IC ${ }_{50}$ concentrations for the samples tested are shown for each drug (median and range). The p values have been calculated using non-parametric statistics, in detail the Wilcoxon matched pairs test. On statistical advice, we chose not to use a Bonferroni's correction, but it should be noted that some technically statistically significant results could have arisen by chance.

\begin{tabular}{|c|c|c|c|c|c|c|c|c|}
\hline \multirow[b]{2}{*}{ Target gene } & \multicolumn{4}{|c|}{ Breast samples $\mathrm{IC}_{50}=18.4 \mu \mathrm{M}(8.9-30.9)$} & \multicolumn{4}{|c|}{ Ovarian samples $\mathrm{IC}_{50}=17.8 \mu \mathrm{M}(6.3-25.6)$} \\
\hline & $\mathbf{n}$ & Control & Cisplatin & $\mathbf{p}$ & $\mathbf{n}$ & Control & Cisplatin & $\mathbf{p}$ \\
\hline ATP7B & 13 & 0.256 & 0.177 & 0.0327 & 7 & 0.268 & 0.111 & 0.4375 \\
\hline ERCCI & 13 & 0.933 & 1.382 & 0.0266 & 7 & 0.542 & 0.758 & 0.0156 \\
\hline MGMT & 13 & 1.203 & 1.275 & 0.8926 & 7 & 0.794 & 0.944 & 0.1094 \\
\hline MLHI & 13 & 0.758 & 1.000 & 0.1465 & 7 & 0.512 & 0.683 & 0.3750 \\
\hline MSH2 & 13 & 1.289 & 1.047 & 0.0479 & 7 & 2.579 & 2.732 & 0.9375 \\
\hline MSH6 & 13 & 2.351 & 2.194 & 0.1909 & 7 & 2.997 & 2.194 & 0.1094 \\
\hline MTII & 13 & 44.221 & 53.817 & 0.5417 & 7 & 12.996 & II.445 & 0.8125 \\
\hline
\end{tabular}

(NER) gene ERCC1 has previously been shown to increase the removal of platinum affected DNA [22]. We observed a significant increase in ERCC1 levels in both tumorderived breast ( $p=0.0266$, Wilcoxon matched pairs test) and ovarian cells ( $\mathrm{p}=0.0156$, Wilcoxon matched pairs test) (Fig 3g). We also observed significant down regulation of a second DNA repair gene, MSH2 in tumor-derived breast cells ( $p=0.0479$, Wilcoxon matched pairs test), but not in tumor-derived ovarian cells. Samimi et al., [23] have previously demonstrated that following cisplatin therapy, there is selection for cells expressing lower hMLH1 and hMSH2. However, no significant changes were observed in the other mismatch repair genes, MLH1 and MSH6 in either tumor type (Table 8).

There was no significant change in MGMT in tumorderived breast or ovarian cells. However, it has previously been shown that MGMT mRNA levels begin to recover after 24 hours in the absence of drug [24]. There was a paradoxical decrease in the copper export pump ATP7B following cisplatin exposure (Table 8), in tumor-derived breast cells ( $p=0.0327$, Wilcoxon matched pairs test), but not in ovarian cells. No significant changes were observed in the heavy-metal binding protein MTII, in either tumor type.

\section{ECF effects in short-term cell culture}

We were able to study tumor-derived cells from 7 esophageal cancer patients, 4 of which had already been given ECF in vivo. The results mirror those obtained from paired esophageal biopsies: we noticed increased expression of TS in the cells that had been exposed to ECF (Fig 3h). However, the expected up-regulation of MDR1 was only detected in 4/7 samples (data not shown), and may therefore be occurring in non-neoplastic cells that do not normally express MDR1, rather than in the neoplastic cells, which we found to express this molecule to the same degree pre- and post-treatment.

\section{Correlation of in vitro cytotoxicity with molecular expression}

Lastly, for 5-FU, doxorubicin and irinotecan, IC90 and IC50 data were obtained by measuring the ATP levels in a small aliquot of cell suspension at the end of the incubation period. This allowed a comparison to be made between drug sensitivity and the expression of putative 
resistance genes in the cells that had been exposed to chemotherapeutic agents. Using multivariate analysis, the IC90 of 5-FU was correlated with the median change of mRNA levels of both TS and DPD measured in 5-FU treated tumor-derived cells compared to control cells (expressed as 2- $-\Delta \Delta \mathrm{Ct})\left(\mathrm{R}^{2}=0.872704 ; \mathrm{p}=0.0006\right.$ for $\mathrm{DPD}$; $\mathrm{p}<0.0001$ for TS). In addition, expression of ERCC1 mRNA correlated with the IC50 values determined for doxorubicin in 11 breast samples $(\mathrm{R}=0.7204, \mathrm{p}<$ $0.0124)$. No other correlations were noted between sensitivity to the drugs and gene expression levels.

\section{Discussion}

Our results suggest that rapid adaptation to chemotherapy may result in a resistant phenotype. This is mediated by down- or up-regulation of genes that are usually correlated to the mechanism of action of the individual chemotherapeutic agent or relevant resistance mechanisms. Our data suggest that short-term cell culture of tumorderived cells with drugs could provide a suitable model for studying resistance mechanisms. The mechanisms observed appeared to be more specific to the drug used than to the tumor type: constitutive resistance probably reflects pre-chemotherapy expression of resistance mechanisms (e.g. drug efflux molecule expression in esophageal carcinoma). Acquired resistance develops rapidly and is likely to reflect changes in gene regulation rather than mutation-dependent selection of clones. Clonal selection may be important in some rapidly growing tumors and cell lines grown in serum-containing media, but is unlikely to be the major factor in solid tumors which have relatively low doubling rates. While mutation-mediated resistance can be much more profound than that observed here, our data suggest that the functional effects may still be sufficient to render the patient's tumor resistant to treatment within one cycle of chemotherapy.

\section{Changes in resistance and target molecules}

A large proportion of the published studies on resistance to chemotherapy have investigated the development of resistance using cell lines generated in the lab after prolonged and step-wise exposure to anti-cancer drugs. These in vitro models are not necessarily representative of the in vivo situation, when patients are usually administered one cycle of chemotherapy every 3-4 weeks. There are few studies in clinical samples. Our approach allows us to expose the tumor cells to single drugs under carefully controlled conditions, even if this would be an inappropriate drug for that particular patient. We are then able to look concomitantly at cytotoxicity, and molecular markers of resistance in the same experiment.

Anthracyclines have a mechanism of action that includes TOPO II $\alpha$ inhibition via DNA intercalation. Resistance to anthracyclines is thought to be mediated by a number of different mechanisms, which include mutation or alteration of its target enzyme, TOPO II $\alpha$, and up-regulation of drug efflux proteins, such as BCRP, MRP1, MVP and MDR1 [25]. Our data show that many of the cell line data are correct: in most solid tumors, it appears that anthracycline and topotecan exposure do lead to decreased topoisomerase II and I expression respectively, while inducing the expression of drug efflux pump molecules. The reason for the alteration in topoisomerase II expression following topotecan exposure is not clear, but topotecan does affect cell proliferation, and any reduction in proliferation would indirectly affect the expression of topoisomerase II alpha induced during $S$ phase. However, our results also suggest that the heterogeneity of chemosensitivity between tumors is reflected by heterogeneity of molecular determinants of resistance/sensitivity.

The increased TS levels in ECF and 5-FU exposed cells is consistent with a number of previous reports. Gene amplification of TS with consequent increases in TS mRNA and protein has been observed in cell lines that are resistant to 5-FU and fluorodeoxyuridine (FUDR) $[26,27]$. Treatment with 5-FU has been shown to acutely induce TS expression in cell lines, animal models and human tumors $[19,28-30]$. In general there is strong evidence that the expression of DPD and TS in GI cancers is predictive of response to 5-FU. It should be noted that the concomitant measurement of both these markers markedly enhanced the ability to predict tumor response to 5-FUbased chemotherapy in a number of studies [31-34].

\section{Gene profiling and drug response}

There are few studies comparing gene expression before and after chemotherapy. A few studies have reported microarray data in biopsy material taken before and after (or even during) chemotherapy. These studies are of great interest, though normal cell effects cannot be excluded from the results. Buchholz et al. [35] employed cDNA microarray to measure gene expression changes during chemotherapy in 5 patients with breast cancer. Clarke et al. [36] studied gene expression changes in 18 rectal cancer patients undergoing therapy with Mitomycin C or 5FU. This study reported a number of genes implicated in protein synthesis and RNA metabolism to be significantly decreased during drug treatment. These studies are not directly comparable: tumors of different types respond better to different drugs, and differences in their adaptation to these drugs are therefore expected on the basis of their innate sensitivity or resistance.

\section{The potential for positive selection: molecular chess}

It is common to show a cross-over effect with clinical trials of treatments with differing mechanisms of action, in which patients treated with one type of chemotherapy show sensitivity to the alternative regimen following fail- 
ure of the one to which they were allocated. The recognition that selection of a molecular phenotype by exposure to one anti-cancer agent may leads to the expression of molecular targets for other drugs raises the possibility that it might be possible to enhance sensitivity to second-line or maintenance therapy by careful selection of patients for first-line therapy [37]. This approach would provide patients with a "backstop" for their first-line chemotherapy. One can envisage a series of interlocking treatments using drugs with specific molecular targets, monitored by molecular assays, which would allow the oncologist to employ a form of molecular chess to defeat the tumor. This approach might overcome the inherent heterogeneity, which is likely to underlie the variable results obtained from sequential chemotherapy to date. Assessment of this process in tumors could provide predictive assays allowing the oncologist to tailor therapy to the patient and avoid the development of resistance within the tumor.

\section{Conclusion}

In summary, this study suggests that up-regulation of resistance genes or down-regulation in target genes may occur rapidly in human solid tumors, within days of the start of treatment, and that similar changes are present in pre- and post-chemotherapy biopsy material. The molecular processes used by each tumor appear to be linked to the drug used, but there is heterogeneity between individual tumors, even those with the same histological type, in the pattern and magnitude of response to the same drugs. Adaptation to chemotherapy may explain why prediction of resistance mechanisms is difficult on the basis of tumor type alone or individual markers, and suggests that more complex predictive methods are required to improve the response rates to chemotherapy.

\section{List of abbreviations}

Gene names were abbreviated as follows: glyceraldehyde3 phosphate dehydrogenase (GAPDH), hypoxanthine phosphoribosyltransferase 1 (HPRT1), human porphobilinogen deaminase (PBGD), succinate dehydrogenase complex-subunit A (SDHA) and TATA box binding protein (TBP), breast cancer resistance protein (BCRP), dihydropyrimidine dehydrogenase (DPD), excision repair cross-complementing 1 (ERCC1) gene, epidermal growth factor receptor (EGFR), glutathione-S-transferase isoform $\pi$ (GST- $\pi)$, multi-drug resistance gene 1 (MDR1), mutL homologue 1 (MLH1), multi-drug resistance related protein 1 (MRP1), multi-drug resistance related protein 2 (MRP2), metallothionein II (MT II), major vault protein (MVP), thymidine phosphorylase (TP), thymidylate synthase (TS), topoisomerase I (TOPO I), topoisomerase II $\alpha$ and $\beta$ (TOPO II).

\section{Competing interests}

IAC is a director of CanTech Ltd. The remaining authors declare that they have no competing interests.

\section{Authors' contributions}

IAC, FDN and SJM conceived and designed the study. FDN, SJM, LAK, PAW, SS, AF and SG participated in the short-term cell culture studies. FDN, SJM, LAK and FGG also carried out the qRT-PCR studies. PJ carried out the immunohisotochemical studies and IAC and SDP carried out histological analysis. IAC, FDN, SJM and BH participated in the statistical analysis. All authors participated in the data analysis, drafting of the manuscript and read and approved the final version.

\section{Acknowledgements}

This project was funded by Portsmouth Hospitals NHS Trust, CanTech Ltd, the BBSRC (Ref 3I/ABYI45I3), the Royal Navy (SJM), the European Commission (grant number BMH4-CT98-9522; FDN), and was supported by a donation from Schering Plough Ltd (LAK). We are grateful to the NHS predictive oncology programme and all the patients, oncologists and surgeons who submitted material for chemosensitivity testing to make this study possible. We thank Christine Seddon for assistance with data entry.

\section{References}

I. Andreotti PE, Linder D, Hartmann DM, Cree IA, Pazzagli M, Bruckner HW: TCA- 100 tumour chemosensitivity assay: differences in sensitivity between cultured tumour cell lines and clinical studies. J Biolumin Chemilumin 1994, 9:373-378.

2. Cree IA, Kurbacher CM, Untch M, Sutherland LA, Hunter EM, Subedi AM, James EA, Dewar JA, Preece PE, Andreotti PE: Correlation of the clinical response to chemotherapy in breast cancer with ex vivo chemosensitivity. Anti-Cancer Drugs 1996, 7:630-635.

3. Matsumoto $\mathrm{Y}$, Takano H, Fojo T: Cellular adaptation to drug exposure: evolution of the drug-resistant phenotype. Cancer Res 1997, 57:5086-5092.

4. Egger G, Liang G, Aparicio A, Jones PA: Epigenetics in human disease and prospects for epigenetic therapy. Nature 2004, 429:457-463.

5. Abolhoda A, Wilson AE, Ross H, Danenberg PV, Burt M, Scotto KW: Rapid activation of MDRI gene expression in human metastatic sarcoma after in vivo exposure to doxorubicin. Clin Cancer Res 1999, 5:3352-3356.

6. Hu XF, Slater A, Kantharidis P, Rischin D, Juneja S, Rossi R, Lee G, Parkin JD, Zalcberg JR: Altered multidrug resistance phenotype caused by anthracycline analogues and cytosine arabinoside in myeloid leukemia. Blood 1999, 93:4086-4095.

7. Stein U, Jurchott K, Schlafke M, Hohenberger P: Expression of multidrug resistance genes MVP, MDRI, and MRPI determined sequentially before, during, and after hyperthermic isolated limb perfusion of soft tissue sarcoma and melanoma patients. J Clin Oncol 2002, 20:3282-3292.

8. Tada Y, Wada M, Migita T, Nagayama J, Hinoshita E, Mochida Y, Maehara $Y$, Tsuneyoshi M, Kuwano $M$, Naito S: Increased expression of multidrug resistance-associated proteins in bladder cancer during clinical course and drug resistance to doxorubicin. Int J Cancer 2002, 98:630-635.

9. Andreotti PE, Cree IA, Kurbacher CM, Hartmann DM, Linder D, Harel G, Gleiberman I, Caruso PA, Ricks SH, Untch M: Chemosensitivity testing of human tumors using a microplate adenosine triphosphate luminescence assay: clinical correlation for cisplatin resistance of ovarian carcinoma. Cancer Research 1995, 55:5276-5282.

10. Wilmanns C, Fan D, O'Brian CA, Bucana CD, Fidler IJ: Orthotopic and ectopic organ environments differentially influence the sensitivity of murine colon carcinoma cells to doxorubicin and 5-fluorouracil. Int J Cancer 1992, 52:98-104. 
II. Hunter EM, Sutherland LA, Cree IA, Subedi AM, Hartmann D, Linder $D$, Andreotti PE: The influence of storage on cytotoxic drug activity in an ATP-based chemosensitivity assay. Anticancer Drugs 1994, 5:17|-176.

12. Vandesompele J, De Preter K, Pattyn F, Poppe B, Van Roy N, De Paepe A, Speleman F: Accurate normalization of real-time quantitative RT-PCR data by geometric averaging of multiple internal control genes. Genome Biology 2002 3:research0034.0031-research0034.00II

13. Applied Biosystems: ABI PRISM 7700 Sequence Detection System user Bulletin \#2. Relative Quantitation of Gene Expression (P/N 4303859B) 1997, 10/2001:I1-15

14. Cree IA: Luminescence-Based cell viability testing. In Bioluminescence Methods and Protocols Edited by: LaRossa RA. Totowa, NJ Humana Press Inc; 1998: 169-177.

15. Kurbacher CM, Cree IA, Brenne U, Bruckner HW, Kurbacher JA, Mallmann $P$, Andreotti $P E$, Krebs $D$ : Heterogeneity of in vitro chemosensitivity in perioperative breast cancer cells to mitoxantrone versus doxorubicin evaluated by a microplate ATP bioluminescence assay. Breast Cancer Res Treat 1996, 4I(2): $|6|-70$

16. Gottesman MM, Fojo T, Bates SE: Multidrug resistance in cancer: role of ATP-dependent transporters. Nat Rev Cancer 2002 , 2:48-58.

17. Borst P, Evers R, Kool M, Wijnholds J: A family of drug transporters: the multidrug resistance-associated proteins. I Natl Cancer Inst 2000, 92:1295-1302.

18. Longley DB, Harkin DP, Johnston PG: 5-fluorouracil: mechanisms of action and clinical strategies. Nat Rev Cancer 2003, 3:330-338.

19. Chu E, Koeller DM, Johnston PG, Zinn S, Allegra C): Regulation of thymidylate synthase in human colon cancer cells treated with 5-fluorouracil and interferon-gamma. Mol Pharmacol 1993, 43:527-533.

20. Wang JC: DNA topoisomerases. Annu Rev Biochem 1996 65:635-692.

21. Foglesong PD, Reckord C, Swink S: Doxorubicin inhibits human DNA topoisomerase I. Cancer Chemother Pharmacol 1992 30: $123-125$

22. Dabholkar M, Vionnet J, Bostick-Bruton F, Yu JJ, Reed E: Messenger RNA levels of XPAC and ERCCI in ovarian cancer tissue correlate with response to platinum-based chemotherapy. J Clin Invest 1994, 94:703-708.

23. Samimi G, Fink D, Varki NM, Husain A, Hoskins WJ, Alberts DS, Howell SB: Analysis of MLHI and MSH2 expression in ovarian cancer before and after platinum drug-based chemotherapy. Clinical Cancer Research: an Official Journal of the American Association for Cancer Research 2000, 6:1415-1421.

24. D'Atri S, Graziani G, Lacal PM, Nistico V, Gilberti S, Faraoni I, Watson A], Bonmassar E, Margison GP: Attenuation of O(6)-methylguanine-DNA methyltransferase activity and mRNA levels by cisplatin and temozolomide in jurkat cells. J Pharmacol Exp Ther 2000, 294:664-67I.

25. Beck WT, Morgan SE, Mo YY, Bhat UG: Tumor cell resistance to DNA topoisomerase II inhibitors: new developments. Drug Resist Updat 1999, 2:382-389.

26. Johnston PG, Drake JC, Trepel J, Allegra C): Immunological quantitation of thymidylate synthase using the monoclonal antibody TS 106 in 5-fluorouracil-sensitive and -resistant human cancer cell lines. Cancer Res 1992, 52:4306-43 I2.

27. Copur S, Aiba K, Drake JC, Allegra CJ, Chu E: Thymidylate synthase gene amplification in human colon cancer cell lines resistant to 5-fluorouracil. Biochem Pharmacol 1995 49:1419-1426

28. Welsh SI, Titley J, Brunton L, Valenti M, Monaghan P, Jackman AL, Aherne GW: Comparison of thymidylate synthase (TS) protein up-regulation after exposure to TS inhibitors in normal and tumor cell lines and tissues. Clin Cancer Res 2000 6:2538-2546

29. Swain SM, Lippman ME, Egan EF, Drake JC, Steinberg SM, Allegra C] Fluorouracil and high-dose leucovorin in previously treated patients with metastatic breast cancer. J Clin Oncol 1989, 7:890-899

30. Peters G], van der Wilt CL, van Triest B, Codacci-Pisanelli G, Johnston PG, van Groeningen CJ, Pinedo HM: Thymidylate synthase and drug resistance. Eur J Cancer | 995, 3 | A: | 299-| 305.
31. Salonga D, Danenberg KD, Johnson M, Metzger R, Groshen S, TsaoWei DD, Lenz HJ, Leichman CG, Leichman L, Diasio RB, Danenberg PV: Colorectal tumors responding to 5-fluorouracil have low gene expression levels of dihydropyrimidine dehydrogenase, thymidylate synthase, and thymidine phosphorylase. Clin Cancer Res 2000, 6: I 322-1327.

32. Ishikawa Y, Kubota T, Otani Y, Watanabe M, Teramoto T, Kumai K Takechi T, Okabe H, Fukushima M, Kitajima M: Dihydropyrimidine dehydrogenase and messenger RNA levels in gastric cancer: possible predictor for sensitivity to 5-fluorouracil. Jpn J Cancer Res 2000, 91: I05-II2.

33. Ichikawa W, Uetake H, Shirota Y, Yamada H, Nishi N, Nihei Z, Sugihara $\mathrm{K}$, Hirayama R: Combination of dihydropyrimidine dehydrogenase and thymidylate synthase gene expressions in primary tumors as predictive parameters for the efficacy of fluoropyrimidine-based chemotherapy for metastatic colorectal cancer. Clin Cancer Res 2003, 9:786-79l.

34. Kornmann M, Schwabe W, Sander S, Kron M, Strater J, Polat S, Kettner E, Weiser HF, Baumann W, Schramm H, Hausler P, Ott K, Behnke D, Staib L, Beger HG, Link KH: Thymidylate synthase and dihydropyrimidine dehydrogenase mRNA expression levels: predictors for survival in colorectal cancer patients receiving adjuvant 5-fluorouracil. Clin Cancer Res 2003, 9:4I I6-4I 24.

35. Buchholz TA, Stivers DN, Stec J, Ayers M, Clark E, Bolt A, Sahin AA, Symmans WF, Hess KR, Kuerer HM, Valero V, Hortobagyi GN, Pusztai L: Global gene expression changes during neoadjuvant chemotherapy for human breast cancer. Cancer J 2002, 8:46I-468.

36. Clarke PA, George ML, Easdale S, Cunningham D, Swift RI, Hill ME, Tait DM, Workman P: Molecular pharmacology of cancer therapy in human colorectal cancer by gene expression profiling. Cancer Res 2003, 63:6855-6863.

37. Kurata T, Tamura K, Kaneda H, Nogami T, Uejima H, Asai Go G, Nakagawa K, Fukuoka M: Effect of re-treatment with gefitinib ('Iressa', ZDI839) after acquisition of resistance. Ann Oncol 2004, I5:173-174.

38. Moniotte S, Vaerman IL, Kockx MM, Larrouy D, Langin D, Noirhomme P, Balligand JL: Real-time RT-PCR for the detection of beta-adrenoceptor messenger RNAs in small human endomyocardial biopsies. I Mol Cell Cardiol 200I, 33:2I2I-2I33.

39. van den Heuvel-Eibrink MM, Wiemer EA, Prins A, MeijerinkJP, Vossebeld PJ, van der Holt B, Pieters R, Sonneveld P: Increased expression of the breast cancer resistance protein (BCRP) in relapsed or refractory acute myeloid leukemia (AML). Leukemia 2002, 16:833-839.

40. Bieche I, Onody P, Laurendeau I, Olivi M, Vidaud D, Lidereau R, Vidaud M: Real-Time Reverse Transcription-PCR Assay for Future Management of ERBB2-based Clinical Applications. Clin Chem 1999, 45:1।48-II56.

4I. Faneyte IF, Kristel PM, Maliepaard M, Scheffer GL, Scheper RJ, Schellens $\mathrm{J}$, van de Vijver MJ: Expression of the breast cancer resistance protein in breast cancer. Clin Cancer Res 2002, 8: I068-1074.

42. Blanquicett C, Gillespie GY, Nabors LB, Miller CR, Bharara S, Buchsbaum DJ, Diasio RB, Johnson MR: Induction of thymidine phosphorylase in both irradiated and shielded, contralateral human U87MG glioma xenografts: implications for a dual modality treatment using capecitabine and irradiation. Mol Cancer Ther 2002, I: I |39- I | 45 .

43. Lord RV, Brabender J, Gandara D, Alberola V, Camps C, Domine M, Cardenal F, Sanchez JM, Gumerlock PH, Taron M, Sanchez JJ, Danenberg KD, Danenberg PV, Rosell R: Low ERCCI expression correlates with prolonged survival after cisplatin plus gemcitabine chemotherapy in non-small cell lung cancer. Clin Cancer Res 2002, 8:2286-2291.

44. Yague E, Armesilla AL, Harrison G, Elliott J, Sardini A, Higgins CF, Raguz S: P-glycoprotein (MDRI) expression in leukemic cells is regulated at two distinct steps, mRNA stabilization and translational initiation. J Biol Chem 2003, 278: I0344-10352.

45. Taipalensuu J, Tornblom H, Lindberg G, Einarsson C, Sjoqvist F, Melhus H, Garberg P, Sjostrom B, Lundgren B, Artursson P: Correlation of gene expression of ten drug efflux proteins of the ATP. binding cassette transporter family in normal human jejunum and in human intestinal epithelial Caco-2 cell monolayers. J Pharmacol Exp Ther 2001, 299: 164-170. 


\section{Pre-publication history}

The pre-publication history for this paper can be accessed here:

http://www.biomedcentral.com/1471-2407/5/78/prepub

Publish with Biomed Central and every scientist can read your work free of charge

"BioMed Central will be the most significant development for disseminating the results of biomedical research in our lifetime. " Sir Paul Nurse, Cancer Research UK

Your research papers will be:

- available free of charge to the entire biomedical community

- peer reviewed and published immediately upon acceptance

- cited in PubMed and archived on PubMed Central

- yours - you keep the copyright

Submit your manuscript here:

http://www.biomedcentral.com/info/publishing_adv.asp
BioMedcentral 